\title{
The Effect of Essential Oil of Thymus vulgaris on the Growth of Bacterial Environmental and Clinical Isolates
}

\author{
Flores-Encarnación M. ${ }^{1 *}$, Acosta-Báez, L.A. ${ }^{1}$, Aguilar-Gutiérrez G.R. ${ }^{2}$, Cabrera-Maldonado C. ${ }^{3}$, \\ Gallardo-Soto H.M. ${ }^{1}$, Sánchez-Herrera A.J. ${ }^{1}$ \\ ${ }^{1}$ Laboratorio de Microbiología Molecular y Celular. Biomedicina, Facultad de Medicina. \\ Benemérita Universidad Autónoma de Puebla. Puebla, Puebla, México. \\ ${ }^{2}$ Centro de Investigación sobre Enfermedades Infecciosas. Instituto Nacional de Salud Pública. Cuernavaca, \\ Morelos. México. \\ ${ }^{3}$ Dpto. de Microbiología. Facultad de Ciencias Químicas. Benemérita Universidad Autónoma de Puebla. \\ Puebla, Puebla, México.
}

*Corresponding Author: M. Flores-Encarnación, Laboratorio 421, Edificio EMA1. Biomedicina. Facultad de Medicina. Benemérita Universidad Autónoma de Puebla. 13 sur 2702, Col. Volcanes, C.P. 72410. Puebla, Puebla, México.

\begin{abstract}
Bacteria have developed resistance mechanisms to evade the effect of antibiotics. The antibiotic resistance is a global problem. Currently, the antimicrobial properties of plant extracts and essential oils and the research of alternatives for treatment of infectious diseases are being studied. It has been observed that essential oils inhibits the growth of pathogenic microorganisms. In the present study, the effect of T. vulgaris on growth of bacterial environmental and clinical isolates was studied.
\end{abstract}

Keywords: Essential oil, Thymus vulgaris, bacteria, antibiotic resistance, bacteria.

\section{INTRODUCTION}

The essential oil of Thymus vulgaris as an antioxidant agent for a long time has been used (Kulisic et al., 2005). Some of its bacteriostatic and bactericidal properties also have also been studied (Borugă et al., 2014). It has been reported that $T$. vulgaris inhibits the growth of some pathogenic microorganisms such as Candida albicans, Legionella sp., Mycobacterium sp., Pseudomonas aeruginosa, Vibrio parahaemolyticus, $V$. fluvialis, Streptococcus pneumoniae, S. mutans, Enterococcus faecalis, Staphylococcus aureus, among others (Billinger et al., 2009; Djeghboub et al., 2018; Oliveira et al., 2017; Oramadike and Ogunbanwo, 2017; Rojas-Armas et al., 2015; Wang et al., 2014). Some of these bacteria have shown to be resistant to the action of antibiotics and they are also capable for forming biofilm on both abiotic and biotic surfaces (Fair and Tor, 2014; Flemming et al., 2016). Biofilms are a population of bacterial cells that grown attached to a surface involved in exopolysaccharide matrix, which protects them from attack by antibiotics or immune system (Costerton et al., 1999; Flores-Encarnación et al., 2014). In this context, it has been reported the presence of pathogenic bacteria forming biofilm inside water pipes commonly used, as well as in catheters of patients hospitalized for long periods of time and who suffer from chronic urinary tract infections (Abdallah et al., 2011; Tsvetanova and Najdenski, 2017). A common problem in water distribution networks is the formation of bacterial biofilms inside them (Ashbolt, 2015; ChavesSimoes and Simoes, 2013; Flores-Encarnación et al., 2016b; Richards et al., 2015; Zhang et al., 2012). Bacterial growth in the water pipes has been of interest in many countries, especially because the pathogenic microorganisms to humans can grow forming biofilm (Chaves-Simões et al., 2013; Costerton, 1999; Flores-Encarnación et al., 2016b; Mahapatra et al., 2015). Availability of potable water devoid of pathogens is fundamental to public health, hovewer water systems are not sterile; they can contain a variety of opportunistic pathogens established as part of the drinking water microbiome (Szewzyk et al., 2000; Wang et al., 2014). It has been proven that hypochlorite has little effect on biofilms. However, chlorine dioxide dosed at a continuous low level, ozone and UV disinfection have been reported for removal and prevention of biofilm from water systems (Mahapatra et al., 2015). In 
the present study, the effect of $T$. vulgaris on growth of bacterial environmental and clinical isolates was studied.

\section{MATERIALS AND METHODS}

\subsection{Source of Material}

In this study a commercial essential oil of $T$. vulgaris was used. As reference commercial essential oils of peppermint, eucalyptus and clove were used. All were obtained from a flavour and fragrance company at Puebla, México.

\subsection{Bacterial Strains}

For this study, Pseudomonas aeruginosa (10 isolations: P1-P10), Escherichia coli (5 isolations: E1E5), Citrobacter freundii (3 isolations: C1-C3) and Klebsiella oxytoca (5 isolations: K1-K5) environmental bacteria were used. The bacterial samples forming biofilm were previously isolated and identified from domestic water pipes commonly used at Puebla municipality, México (FloresEncarnación et.al, 2016b). 10 strains of uropathogenic E. coli from clinical isolates also were used. The strains were provided by some diagnostic laboratories at Puebla city. The identity of uropathogenic $E$. coli strains was confirmed by using the microbial biochemical tests described by Fernández-Olmos et al., (2010). Bacterial strains were stored at $-40^{\circ} \mathrm{C}$ in tryptic soy broth with $20 \%$ glycerol until analysis. As reference E. coli CFT073 strain was used.

\subsection{Culture}

The tripticasein soy broth was used for bacterial culture. For that, a total of $125 \mu \mathrm{L}$ of each bacterial strain was inoculated in $5 \mathrm{~mL}$ of tripticasein soy broth and incubated overnight at $37^{\circ} \mathrm{C}$ during 24 hours (preculture). The growth in plate was assayed on tripticasein soy agar plates. Bacteria were inoculated in cross groove on tripticasein soy agar plates and it was incubated at $37^{\circ} \mathrm{C}$ for 24 hours.

\subsection{Effect of T. vulgaris}

The effect of essential oil was determined using the technique of disk diffusion in agar using discs impregnated with essential oil of T. vulgaris. Briefly, tripticasein soy agar plates containing $20 \mathrm{~mL}$ of medium were prepared. Sterile Petri dishes $(60 \times 100 \mathrm{~mm})$ were used. Plates were inoculated by crossstriation with bacterial strains. Each inoculum contained approximately $1 \times 10^{6} \mathrm{CFU} \mathrm{mL}{ }^{-1}$. Then, sterile filter paper disks ( $5 \mathrm{~mm}$ diameter) were placed on the surface of tripticasein soy agar plates. Different concentrations of the essential oil were added: 1.3, 2.6, 3.9, 6.5 and $13 \mu \mathrm{g}$. The agar plates were incubated at $37^{\circ} \mathrm{C}$ for 24 hours. As a comparison, the assay also was done using peppermint, eucalyptus and clove essential oils. Different concentrations ( 1 to $10 \mu \mathrm{g})$ of the essential oil were added: peppermint, eucalyptus and rosemary. The analyses were conducted in triplicate.

\subsection{Antibiotic Sensitivity Test}

As reference, the antibiotic sensitivity test of uropathogenic E. coli strains was done. For this, the antibiotic diffusion plate technique was used. The discs with antibiotics used: ampicillin $(10 \mu \mathrm{g})$, oxacillin $(1 \mu \mathrm{g})$, chloramphenicol $(30 \mu \mathrm{g})$ and furazolidone $(100 \mu \mathrm{g})$ (BBL, Sensi-Disc, Oxoid discs). The bacteria was incubated overnight at $37^{\circ} \mathrm{C}$ during 24 hours. After twenty-four hours proceeded to make the measurement of growth inhibition. Then it proceeded to compare the results with the parameters of sensitivity and resistance following the rules of Clinical and Laboratory Standards Institute. The diameter of zone of inhibition of growth was recorded. The antibiotic sensitivity test for bacteria forming biofilm in domestic water pipes was determined in a previous work (FloresEncarnación et.al, 2016a).

\section{RESUltS}

In this study, 30 bacterial strains were used which 20 strains were recovered from biofilm formed inside water pipes. The bacterial strains forming biofilm were previously isolated and identified from domestic water pipes commonly used at Puebla. The remaining 10 were strains of uropathogenic $E$. coli from clinical isolates (patients with urinary tract infection). The latter were provided by diagnostic laboratories of Puebla city. The Table 1 shows bacterial strains from environmental and clinical isolates. The identity of bacterial strains was confirmed by using the microbial biochemical tests as described in Material and Methods. As seen in Table 1, P. aeruginosa, E. coli, Citrobacter 
freundii and Klebsiella oxytoca were the bacteria recovered from the interior of water pipes (environmental strains), as soon as the clinical isolates (from urinary tract infection) included 10 strains of uropathogenic E. coli. On the other hand, the effect of essential oil of f $T$. vulgaris was determined using the technique of disk diffusion on agar as described in Material and Methods. So, the discs were impregnated with different concentrations of essential oil: 1.3, 2.6, 3.9, 6.5 and $13 \mu \mathrm{g}$. The results obtained were shown in Fig. 1. The Fig. 1A shows the surface of a tripticasein soy agar plate where bacterial strains from environmental isolates were cultured, observing that the growth was completely inhibited for the different concentrations of $T$. vulgaris used. The same effect was observed when E. coli, $C$. freundii and $K$. oxytoca strains were subjected to essential oil. In the case of P. aeruginosa, one of the strains was not as sensitive to the presence of T. vulgaris. The use of 1.3 to $3.9 \mu \mathrm{g}$ of essential oil caused the formation of growth inhibition halos (data not shown). As mentioned earlier, 10 strains of uropathogenic E. coli from clinical isolates also were assayed. The results obtained were shown in Fig. 1B. As can be seen in Fig. 1B, the trypticasein soy agar surface lacked bacterial growth and the surface of the agar acquired a bright appearance. In all strains of uropathogenic E. coli a strong inhibitory effect of growth was observed. The results obtained indicated that $T$. vulgaris showed a potent inhibitory effect on the growth of uropathogenic E. coli at the concentrations of the essential oil tested. In all cases, the results obtained indicated a bactericidal effect because the growth was not recorded (data not shown). As a comparison, the effect of thyme, peppermint, eucaliptus and rosemary essential oils was determined using an uropathogenic $E$. coli CFT 073 strain. The results obtained were shown in Fig. 2. As can be seen, thyme essential oil showed the greatest inhibitory effect on growth of uropathogenic E. coli (Fig. 2A). The essential oils of peppermint, eucalyptus and rosemary showed a lower inhibitory effect on the growth of uropathogenic E. coli at the concentrations tested (Fig. 2B, 2C, 2D). On the other hand, the antibiotic sensitivity test was done (as reference). In previous work, the sensitivity to antibiotics of some strains forming biofilm in water pipes was determined (data not shown). In the present study, the antibiotic sensitivity for uropathogenic E. coli strains (from urinary tract infection) was done. The diffusion plate technique was made using discs with ampicillin, oxacillin, chloramphenicol and furazolidone as described in Material and Methods. The results obtained shown that all uropathogenic E. coli strains were resistant to ampicillin and oxacillin and they were sensitive to chloramphenicol and furazolidone. In the antibiotic sensitivity tests, the growth inhibition zone obtained using chloramphenicol and furazolidone discs measured 22 to $30 \mathrm{~mm}$ in diameter for the concentrations tested (30 and $100 \mu \mathrm{g}$, respectively) (data not shown). However, in none of the cases a strong inhibition of bacterial growth was observed, as it happened using the essential oil of $T$. vulgaris.

Table1. The bacterial strains from environmental and clinical isolates.

\begin{tabular}{|c|l|}
\hline Bacterial strain & \multicolumn{1}{|c|}{ From } \\
\hline Pseudomonas aeruginosa 1 & Forming biofilm in water pipes \\
\hline Pseudomonas aeruginosa 2 & Forming biofilm in water pipes \\
\hline Pseudomonas aeruginosa 3 & Forming biofilm in water pipes \\
\hline Pseudomonas aeruginosa 4 & Forming biofilm in water pipes \\
\hline Pseudomonas aeruginosa 5 & Forming biofilm in water pipes \\
\hline Pseudomonas aeruginosa 6 & Forming biofilm in water pipes \\
\hline Pseudomonas aeruginosa 7 & Forming biofilm in water pipes \\
\hline Pseudomonas aeruginosa 8 & Forming biofilm in water pipes \\
\hline Pseudomonas aeruginosa 9 & Forming biofilm in water pipes \\
\hline Pseudomonas aeruginosa 10 & Forming biofilm in water pipes \\
\hline Escherichia coli 1 & Forming biofilm in water pipes \\
\hline Escherichia coli 2 & Forming biofilm in water pipes \\
\hline Escherichia coli 3 & Forming biofilm in water pipes \\
\hline Escherichia coli 4 & Forming biofilm in water pipes \\
\hline Escherichia coli 5 & Forming biofilm in water pipes \\
\hline Citrobacter freundii 1 & Forming biofilm in water pipes \\
\hline Citrobacter freundii 2 & Forming biofilm in water pipes \\
\hline Citrobacter freundii 3 & Forming biofilm in water pipes \\
\hline Klebsiella oxytoca 1 & Forming biofilm in water pipes \\
\hline Klebsiella oxytoca 2 & Forming biofilm in water pipes \\
\hline Klebsiella oxytoca 3 & Forming biofilm in water pipes \\
\hline
\end{tabular}


The Effect of Essential Oil of Thymus vulgaris on the Growth of Bacterial Environmental and Clinical Isolates

\begin{tabular}{|c|l|}
\hline Uropathogenic $E$. coli 1 & Urinary tract infection \\
\hline Uropathogenic $E$. coli 2 & Urinary tract infection \\
\hline Uropathogenic $E$. coli 3 & Urinary tract infection \\
\hline Uropathogenic $E$. coli 4 & Urinary tract infection \\
\hline Uropathogenic $E$. coli 5 & Urinary tract infection \\
\hline Uropathogenic $E$ coli 6 & Urinary tract infection \\
\hline Uropathogenic $E$. coli 7 & Urinary tract infection \\
\hline Uropathogenic $E$. coli 8 & Urinary tract infection \\
\hline Uropathogenic $E$. coli 9 & Urinary tract infection \\
\hline Uropathogenic $E$. coli 10 & Urinary tract infection \\
\hline
\end{tabular}

\section{DISCUSSION}

The essential oils have been used for flavored foods and beverages; they have been used to disguise unpleasant odors and control health problems in humans and animals (Franz et al., 2010; Teles Andrade et al., 2014). The essentil oils are typically liquid, colored, volatile. They are synthesized by aromatic plants as secondary metabolites in several plant organs (flowers, leaves, stems, branches, seeds, roots, bark) and they are characterized by a strong odor (Bakkali et al., 2008). It has been reported that the essential oils have several biological properties, such as larvicidal action, antioxidant, analgesic and anti-inflammatory, fungicide and antitumor activity (Carmo et al., 2008; Mendes et al., 2010; Rajkumar et al., 2010; Silva et al., 2008; Wannes et al., 2010). Unfortunately, the marked increase in antimicrobial resistance among common bacterial pathogens is now threatening this therapeutic. The World Health Organization has named antibiotic resistance as one of the three most important public health threats of the $21^{\text {st }}$ century (Munita and Arias, 2016). In recent years there has been increasing interest in the use of biologically active organic compounds which are extracted from plant species that have the ability to eliminate pathogenic microorganisms by themselves; this is mainly due to the resistance that microorganisms have developed to antibiotics (Daferera et al., 2003; Flores-Encarnación et al., 2016c; Marston et al., 2016). The antimicrobial activity of essential oils has been researched against a variety of microorganisms (López et al., 2005). However, the emergence of multidrugresistant bacteria poses a challenge to treating infections, so the need to find new substances with antimicrobial properties for use in the fight against these microorganisms is evident (Hemaiswarya et al., 2008; Pereira et al., 2004; Teles Andrade et al., 2014). In the present study, the effect of $T$. vulgaris on growth of bacterial environmental and clinical isolates was studied. For that, 20 strains were recovered from biofilm formed inside water pipes and 10 were strains of uropathogenic E. coli from clinical isolates. The antimicrobial activity was determined using the technique of disk diffusion in agar and antimicrobial susceptibility test discs. As it was observed, the growth of bacterial strains from environmental isolates was completely inhibited at the different concentrations of $T$. vulgaris used. The same effect was observed when $E$. coli, $C$. freundii and $K$. oxytoca strains were subjected to essential oil (Fig. 1). One of the strains of $P$. aeruginosa was not as sensitive to the presence of $T$. vulgaris where it was observed the formation of growth inhibition halos (data not shown). It has been reported that the pathogenic bacteria to humans can grow forming biofilm inside water pipes which it has been of interest in world (FloresEncarnación et al., 2016b; Mahapatra et al., 2015). Bacteria forming biofilms are surrounded by a exopolymer matrix that binds them to water storage tanks and pipes (Flores-Encarnación et al., 2016b). Bacteria settle on the inner surfaces of pipes and form biofilm which becomes them the source of secondary microbial contamination of water (Rożej et al., 2015). As mentioned earlier, the results obtained shown that the essential oil of $T$. vulgaris inhibited completely the growth from environmental isolates at low concentration. To the concentrations tested (1.3 to $13 \mu \mathrm{g}$ of essential oil), the growth of bacteria was totally dejected. The effect was bactericidal as could be demonstrated from the reseeding that was done it not having recorded subsequent growth in a fresh culture medium (data not shown). It has been reported that T. vulgaris extract strongly inhibited the growth of $P$. aeruginosa and $S$. aureus but it inhibited poorly the growth of Bacillus cereus and E. coli (Mohsenipour and Hassanshahian, 2015). It has been reported several chemical components, such as thymol, carvacrol and eugenol, are the most active constituents of T. vulgaris which destabilizes the bacterial cytoplasmic membrane (Al-Shuneigat et al., 2014).

As mentioned earlier, the uropathogenic E. coli strains from clinical isolates also were assayed. The results shown a strong inhibitory effect on growth from all strains of uropathogenic E. coli tested: the 
trypticasein soy agar surface lacked bacterial growth and the surface of the agar acquired a bright appearance (Fig. 1B). The results obtained shown that the essential oil of T. vulgaris inhibited completely the growth from clinical isolates at low concentration $(1.3$ to $13 \mu \mathrm{g})$. Biofilm formation is an important step in the pathogenicity of bacteria because biofilm increases the resistance to antibiotics as well as to the immune system, for example: cells living in biofilm are about 1000 times more resistant to antimicrobial agents (Al-Shuneigat et al., 2014; Costerton et al., 1999). It has been reported that the most common infections caused by biofilms are urinary tract infections being uropathogenic E. coli the infectious agent that is most frequently isolated (Flores-Mireles et al., 2015; Foxman et al., 2014; Salehzadeh and Zamani, 2018). Other infectious agent living in biofilm are related to use of catheters (by S. epidermidis), middle-ear infections in children (by Haemophilus influenzae), tooth decay (by $S$. mutans), burns, wound infection, lung infection (by $P$. aeruginosa) (Al-Shuneigat et al., 2014). In the present study, the antibiotic sensitivity for uropathogenic E. coli strains was done using ampicillin, oxacillin, chloramphenicol and furazolidone. The results shown that all uropathogenic E. coli strains were resistant to ampicillin and oxacillin; they were sensitive to chloramphenicol and furazolidone. However, in none of the cases a strong inhibition of bacterial growth was observed, as it happened using the essential oil of T. vulgaris. This result could be explained by the effectiveness of essential oil components for alter the permeability of the bacterial wall, such as phenols and monoterpenes which are responsible for the irreversible damage in the membrane and the cellular walls (Winward et al. 2002). It has been reported also that the essential oils have high penetrability and are more effective acting on organized biofilm than antibiotics (AlShuneigat et al., 2014). To compare the effect produced by the essential oil of T. vulgaris on bacterial growth, in this study the thyme, peppermint, eucaliptus and rosemary essential oils was tested using an uropathogenic E. coli CFT 073 strain (Fig. 2). The results shown that the thyme essential oil produced the greatest inhibitory effect on bacterial growth. The essential oils of peppermint, eucalyptus and rosemary showed a lower inhibitory effect on the growth of uropathogenic E. coli at the concentrations tested.

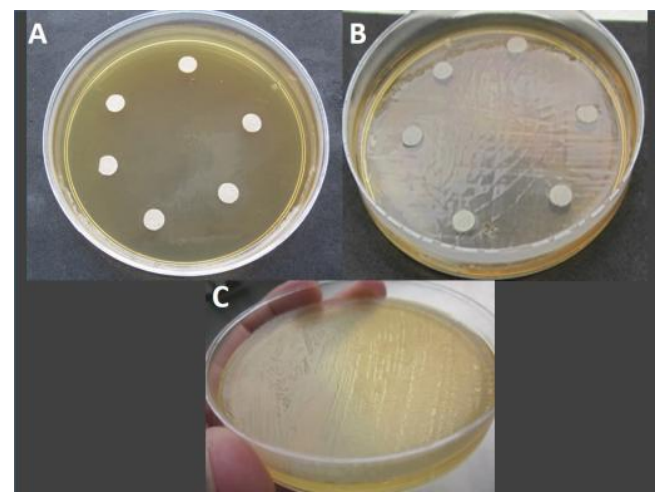

Fig1. The effect of essential oil of T. vulgaris on the growth of bacterial environmental and clinical isolates. A. The growth was completely inhibited by T. vulgaris in strains from environmental isolates (forming biofilm in water pipes); B. All strains of uropathogenic E. coli from clinical isolates have a strong inhibitory effect on growth; C. Control condition.

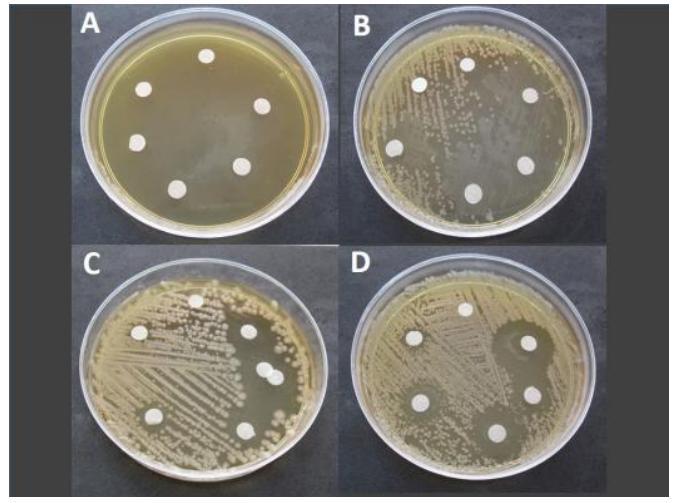

Fig2. The effect of some essential oils on growth of uropathogenic E. coli. A. Thyme; B. Peppermint; C. Eucaliptus; D. Rosemary. In all cases, 1 to $10 \mu \mathrm{g}$ of essential oil were used and placed in increasing concentrations in the counterclockwise direction. 


\section{CONCLUSION}

In the present study was possible to conclude that the essential oil of T. vulgaris was a potent inhibitor of growth from clinical uropathogenic E. coli and environmental isolates strains. Given the current problem that has generated the antibiotic resistance is necessary the research of alternatives for treatment of infectious diseases using essential oils and plant extracts with antimicrobial activity.

\section{ACKNOWLEDGEMENT}

Thank to PRODEP and Facultad de Medicina-BUAP for the facilities provided for the development of this work. Thank to Martínez-Flores L.D. for their valuable technical support to carry out this work.

\section{REFERENCES}

[1] Abdallah N.M.A., Elsayed S.B., Mostafa M.M.Y., El-gohary G.M. (2011). Biofilm forming bacteria isolated from urinary tract infection, relation to catheterization and susceptibility to antibiotics. Int. J. Biotechnol. Mol. Biol. Res. 2:172-178.

[2] Al-Shuneigat J., Al-Sarayreh S., Al-Saraireh Y., Al-Qudah M., Al-Tarawneh I. (2014). Effects of wild Thymus vulgaris essential oil on clinical isolates biofilm-forming bacteria. IOSR J. Dental and Med. Sci. 13:62-66.

[3] Ashbolt N.J. (2015). Microbial contamination of drinking water and human health from community water systems. Curr. Environ. Health Rep. 5:95-106.

[4] Bakkali F., Averbeck S., Averbeck D., Idaomar M. (2008). Biological effects of essential oils-A review. Food Chem. Toxicol. 46:446-475.

[5] Billinger M.E., Olivier K.N., Viboud C., de Oca R.M., Steiner C., Holland S.M., Prevots D.R. (2009). Non tuberculous mycobacteria associated lung disease in hospitalized persons, United States, 1998-2005. Emerg. Infect. Dis. 15:1562-1569.

[6] Borugă O., Jianu C., Mişcă C., Goleț I., Gruia A.T., Horhat F.G. (2014). Thymus vulgaris essential oil: chemical composition and antimicrobial activity. J. Med. Life. 7:56-60.

[7] Carmo E.S., Lima E.O., Souza E.L. (2008). The potential of Origanum vulgare L. (Lamiaceae) essential oil in inhibiting the growth of some food-related Aspergillus species. Braz. J. Microbiol. 39:362-367.

[8] Chaves-Simões L. and Simões M. (2013). Biofilms in drinking water: problems and solutions. RSC Adv. 3:2520-2533.

[9] Costerton J.W., Stewart P.S., Greenberg E.P. (1999). Bacterial biofilms: a common cause of persistent infections. Science. 284:1318-1322.

[10] Daferera D.J., Ziogas B.N., Polissiou M.G. (2003). The effectiveness of plant essential oils in the growth of Botrytis cinerea, Fusarium sp. and Clavibacter michiganensis subsp. michiganensis. Crop. Protect. 22:39-44.

[11] Djeghboub S., Oumouna M., Benyahia N. (2017). Evaluation of the anti-bacterial activity of thyme (Thymus vulgaris) and rosemary (Romarinus officinalis) essential oils on Pseudomonas aeruginosa. In: Kallel A., Ksibi M., Ben Dhia H., Khélifi N. (eds) Recent Advances in Environmental Science from the Euro-Mediterranean and Surrounding Regions. EMCEI. Advances in Science, Technology \& Innovation (IEREK Interdisciplinary Series for Sustainable Development). Springer, Cham.

[12] Fair R.J. and Tor Y. (2014). Antibiotics and Bacterial Resistance in the 21st Century. Persp. Med. Chem. 6:25-64.

[13] Fernández-Olmos A., García-de la Fuente C., Saéz-Nieto J.A., Valdezate-Ramos S. (2010). Métodos fenotípicos de identificación. En: Métodos de identificación bacteriana en el laboratorio de microbiología. Ed. Cercenado E. y Cantón, R. Madrid, España. pp 31-43.

[14] Flemming H.C., Wingender J., Szewzyk U., Steinberg P., Rice S.A., Kjelleberg S. (2016). Biofilms: an emergent form of bacterial life. Nat. Rev. Microbiol. 14:563-575.

[15] Flores-Encarnación M., González-Gutiérrez J.Y., Meza de la Rosa J.L., Cabrera-Maldonado C., CarreñoLópez R., Nava Nolazco R.M., García-García S., León-Tello G. (2014). The bacterial biofilm and importance to human health. Basic Res J Med Clin Sci. 3:28-32.

[16] Flores-Encarnación M,, Hernández-Román J,, Aguilar-Gutiérrez G.R,, Cabrera-Maldonado C., LópezGarcía A., Ruíz-Tagle A., León-Tello G. (2016a). The antibiotic resistance by bacteria forming biofilm into water pipes. Int. J. Res. Stu. Biosc. 4:49-53.

[17] Flores-Encarnación M., Jaramillo-Rodríguez J.B., Xicohténcatl-Cortés J., Amador-Bravo D., AguilarGutiérrez G.R., Cabrera-Maldonado C., León-Tello G., Ruíz-Tagle A., López-García A., Meneses- 
Sánchez M.C. (2016b). The presence of bacteria forming biofilm in wáter pipes commonly used at Puebla, México. Int. J. Curr. Res. 8:25961-25965.

[18] Flores-Encarnación M., Nava-Nolazco R.M., Carreño-López R., Aguilar-Gutiérrez G.R., García-García S.C., Cabrera-Maldonado C. (2016c). The antibacterial effect of plant-based essential oils. Int. J. Res. Studies Biosci. 4: 1-6.

[19] Flores-Mireles A.L., Walker J.N., Caparon M. and Hultgren S.J. (2015). Urinary tract infections: epidemiology, mechanisms of infection and treatment options. Nat. Rev. Microbiol. 13:269-284.

[20] Foxman B. (2014). Urinary tract infection syndromes: occurrence, recurrence, bacteriology, risk factors, and disease burden. Infect. Dis. Clin. North Am. 28:1-13.

[21] Franz C.M. (2010). Essential oil research: Past, present and future. Flavour Fragr. J. 25:112-113.

[22] Hemaiswarya S, Kruthiventi A.K, Doble M. (2008). Synergism between natural products and antibiotics against infectious diseases. Phytomed. 15:639-652.

[23] Kulisic T., Radonic A., Milos M. (2005). Antioxidant properties of thyme (Thymus vulgaris L.) and wild thyme (Thymus serpyllum L.) essential oils. Ital. J. Food Sci. 17:1-10.

[24] López P., Sánchez C., Batlle R., Nerín C. (2005). Solidand vapor-phase antimicrobial activities of six essential oils: Susceptibility of selected foodborne bacterial and fungal strains. J. Agric. Food Chem. 53:6939-6946.

[25] Mahapatra A., Padhi N., Mahapatra D., Bhatt M., Sahoo D., Jena S., Dash D., Chayani N. (2015). Study of biofilm in bacteria from water pipelines. J. Clin. Diag. Res. 9:9-11.

[26] Marston H.D., Dixon D.M., Knisely J.M., Palmore T.N., Fauci A.S. (2016). Antimicrobial resistance. JAMA. 316:1193-1204.

[27] Mendes S.S., Bomfim R.R., Jesus H.C.R., Alves P.B., Blank A.F., Estevam C.S., Antoniolli A.R., Thomazzi S.M. (2010). Evaluation of the analgesic and anti-inflammatory effects of the essential oil of Lippia gracilis leaves. J. Ethnopharmacol. 129:391-397.

[28] Mohsenipour Z. and Hassanshahian M. (2015). The inhibitory effect of Thymus vulgaris extracts on the planktonic form and biofilm structures of six human pathogenic bacteria. Avicenna J. Phytomed. 5:309-318.

[29] Munita J.M. and Arias C.A. (2017). Mechanisms of antibiotic resistance. Microbiol. Spectrum. 4:1-24.

[30] Oliveira J.R., De Jesús Viegas D., Martins A.P.R., Carvalho C.A.T., Soares C.P., Camargo S.E.A., De Oliveira L.D. (2017). Thymus vulgaris L. extract has antimicrobial and anti-inflammatory effects in the absence of cytotoxicity and genotoxicity. Arch. Oral Biol. 82:271-279.

[31] Oramadike C.E. and Ogunbanwo S.T. (2017). Antagonistic activity of Thymus vulgaris extracts against Vibrio species isolated from seafoods. J. Food Sci. and Technol. 54:1199-1205.

[32] Pereira R.S., Sumita T.C., Furlan M.R., Jorge A.O.C., Ueno M. (2004). Atividade antibacteriana de óleos essenciais em cepas isoladas de infecção urinária. Rev. Saude Publica. 2:326-328.

[33] Rajkumar S. and Jebanesan A. (2010). Chemical composition and larvicidal activity of leaf essential oil from Clausena dentata (Willd) M. Roam. (Rutaceae) against the chikungunya vector, Aedes aegypti Linn. (Diptera: Culicidae). J. Asia Pac. Entomol. 13:107-109.

[34] Richards C.L., Broadaway S.C., Eggers M.J., Doyle J., Pyle B.H., Camper A.K., Ford T.E. (2015). Detection of pathogenic and non-pathogenic bacteria in drinking water and associated biofilms on the crow reservation, Montana, USA. Microbiol. Ecol. 10:1-12.

[35] Rojas-Armas J., Ortiz-Sánchez J., Jáuregui-Maldonado J., Ruiz-Quiroz J., Almonacid Román R. (2015). Aceite esencial de Thymus vulgaris L (tomillo), su combinación con EDTA contra Candida albicans y formulación de una crema. Anal. Facultad de Medicina. 76:235-240.

[36] Rożej A., Cydzik-Kwiatkowska A., Kowalska B., Kowalski D. (2015). Structure and microbial diversity of biofilms on different pipe materials of a model drinking water distribution systems. World J. Microbiol. Biotechnol. 31:37-47.

[37] Salehzadeh A. and Zamani H. (2018). Characterization of (uropathogenic) E. coli isolated from urinary tract infections: phylogenetic typing and distribution of virulence-associated traits. Brit. J. Biom. Sci. 75:40-42.

[38] Silva S.L., Chaar J.S., Figueiredo P.M.S., Yano T. (2008). Cytotoxic evaluation of essential oil from Casearia sylvestris Sw on human cancer cells and erythrocytes. Acta Amazonica. 1:107-112.

[39] Szewzyk U., Szewzyk R., Manz W., Schleifer K.H. (2000). Microbiological safety of drinking water. Annu. Rev. Microbiol. 54:81-127.

[40] Teles Andrade B.F.M., Nunes Barbosa L., da Silva Probst I., Fernandes Júnior A. (2014). Antimicrobial activity of essential oils. J. Essential Oil Res. 26:34-40. 
[41] Tsvetanova Z. and Najdenski H. (2017). Pathogenic bacteria in waters and drinking water associated biofilms. Ecol Eng Environ Protection. 1:50-61.

[42] Wang H., Masters S., Edwards M.A., Falkinham J.O., Pruden A. (2014). Effect of disinfectant, water age, and pipe materials on bacterial and eukaryotic community structure in drinking water biofilm. Environ. Sci. Technol. 48:1426-1435.

[43] Wannes W.A., Mhamdi B., Sriti J., Jemia M.B., Ouchikh O., Hamdaoui G., Kchouk M.E., Marzou B. (2010). Antioxidant activities of the essential oils and methanol extracts from myrtle (Myrtus communis var. italica L.) leaf, stem and flower. Food Chem. Toxicol. 48:1362-1370.

[44] Winward G.P., Avery L.M., Stephenson T., Jefferson B. (2002). Essential oils for the disinfection of grey water. Tech. Rep. Ser. 905:1-109.

[45] Zhang M., Liu W., Nie X., Li C., Gu J., Zhang C. (2012). Molecular analysis of bacterial communities in biofilms of a drinking water clearwell. Microbes Environ. 27:443-448.

Citation: Flores-Encarnación M., et.al. "The Effect of Essential Oil of Thymus vulgaris on the Growth of Bacterial Environmental and Clinical Isolates" International Journal of Research Studies In Biosciences (Ijrsb), Vol. 7, no. 5, pp. 26-33, 2019. http://Dx.Doi.org/10.20431/2349-0365.0705004

Copyright: (C) 2019 Authors. This is an open-access article distributed under the terms of the Creative Commons Attribution License, which permits unrestricted use, distribution, and reproduction in any medium, provided the original author and source are credited. 